Original Research Article

\title{
Sociodemographic profile of patients and prescribing trend of drugs in organophosphate poisoning at tertiary care teaching hospital in Central India: a descriptive study
}

\author{
Sudharam T. Bhagwate ${ }^{1}$, Rupesh A. Warbhe ${ }^{1 *}$, Girish K. Chavhan ${ }^{1}$, \\ Anita H. Yuwnate ${ }^{1}$, Anil D. Wankhade ${ }^{2}$
}

${ }^{1}$ Department of Pharmacology, Government Medical College Akola, Maharashtra, India ${ }^{2}$ Government Medical College Akola, Maharashtra, India

Received: 27 February 2019

Revised: 20 March 2019

Accepted: 03 April 2019

\section{*Correspondence to:}

Dr. Rupesh A. Warbhe, Email: warbherupesh5 @ gmail.com

Copyright: (C) the author(s), publisher and licensee Medip Academy. This is an openaccess article distributed under the terms of the Creative Commons Attribution NonCommercial License, which permits unrestricted noncommercial use, distribution, and reproduction in any medium, provided the original work is properly cited.

\begin{abstract}
Background: India is an agrarian country, where pesticides are most widely used in farming. Monsoon dependent agricultural practices are common in India. In present study socioeconomic class and prescribing pattern of commonly used drugs in organophosphate poisoning in indoor setting at tertiary care hospital is evaluated. The aim of the study was to evaluate prescribing trend of drugs and socioeconomic class of patients in organophosphate poisoning in monsoon season.

Methods: Prospective observational study was conducted at Medical Intensive Care Unit (MICU) and Medicine Wards for 4 months at 540 bedded tertiary care teaching hospital.

Results: Total 64 diagnosed cases were enrolled and analyzed in present study $(\mathrm{n}=64)$. Maximum number of cases $(57.81 \%)$ were male followed by female $(42.18 \%)$. Most of the cases $(37.50 \%)$ were from the age group of 21-30 years. $49(76.56 \%)$ patients were of primary intentional poisoning followed by 15 $(23.43 \%)$ patients of accidental poisoning. Most common drugs prescribed were atropine, pralidoxime, cefotaxime and ranitidine. The average amount of atropine and pralidoxime used per patient/day were $37.89 \pm 63.63 \mathrm{mg}$ and $10.07 \pm 26.87 \mathrm{gm}$ respectively.

Conclusions: Present study revealed that young male adults with low socioeconomic class from rural background were prone for intentional organophosphate poisoning in central India.
\end{abstract}

Keywords: Atropine, Organophosphate, OPP, Pesticides, Pralidoxime, WHO prescribing indicators

\section{INTRODUCTION}

Poisoning with organophosphorus compound is a global public health problem. According to World Health Organization (WHO), 3 Million cases of pesticides (mainly O P compounds) poisoning occur every year, resulting in excess of 2.50 thousand deaths. ${ }^{1}$ India is a predominantly agrarian country where pesticides are widely used for farming. As per estimates of National Crime Bureau of India, suicides by consumption of pesticides account for $19.4 \%$ and $19.7 \%$ of all cases of suicidal poisoning in the year 2006 and 2007 respectively. ${ }^{2}$ Rapid industrialization and massive use of pesticides in agriculture has increased the incidence of poisoning. In India, as agriculture is the backbone of the country, insecticides are used to a greater extent and the poisoning with such agents are more common. ${ }^{3}$

Organophosphorus compounds are diverse group of chemicals esters, amides or thiol derivatives of phosphoric acid. According to the toxicity caused by organophosphates (OP) they are classified as mild, 
moderate and highly toxic. ${ }^{4}$ Majority of patients of the $\mathrm{O}$ $\mathrm{P}$ Poisoning belong to the younger generation less than 30 years and is self-intentional. ${ }^{5}$ Organophosphates (OP) compound are principally used as agricultural insecticides due to their easy accessibility and they are responsible for loss of lives in rural areas and to considerable extent in urban areas also. $^{6}$ Pesticides are classified as organophosphorus and non-organophosphorus compounds. Monocrotophos phorate and methomyl are class I toxic pesticides as per WHO. ${ }^{7}$ Atropine is highly effective in counteracting muscarinic symptoms but does not reverse peripheral muscular paralysis; it is given in the dose of $2 \mathrm{mg}$ intravenous (IV) repeated every 10 minutes until dryness of mouth or other signs of atropinization appear. ${ }^{8}$ Pralidoxime is cholinesterase re-activator useful in OP poisoning and anti-cholinesterase poisoning. It causes faster reactivation of the enzyme if started early within hours before the ageing of enzymes occurs. It is injected IV slowly in the dose of 28 to $30 \mathrm{mg} / \mathrm{kg}$ IV loading dose followed by $8-10 \mathrm{mg} / \mathrm{kg} / \mathrm{hr}^{9}{ }^{9}$ This study was undertaken due to scarce data available on drug utilization in organophosphate poisoning patients and their socioeconomic status in this geographical region of central India.

\section{METHODS}

The prospective observational drug utilization study was conducted at 540 bedded tertiary care teaching hospital in central India. Total 64 patients were enrolled $(n=64)$ after confirming diagnosis of OPP and approval by institutional ethics committee. The study duration was 4 months from May to August 2018.

\section{Data source}

Indoor case papers of the patients admitted in the medicine ward (male and female) and MICU (Medical Intensive Care Unit) of tertiary care teaching hospital were screened.

\section{Inclusion criteria}

Case papers of adult patients $\geq 18$ years of age diagnosed by clinician as organophosphate poisoning willing to give written consent to share socioeconomic information were enrolled for the study.

\section{Exclusion criteria}

- Patients $<18$ years of age,

- Critically ill,

- And cases discharged against medical advice.

\section{Data collection}

The study parameters in predesigned format like demographic data, duration of hospital stay, diagnosis, treatment delivered, and drug schedule were recorded during their stay in the hospital. For analyzing socioeconomic class modified Kuppuswamy scale was applied in which occupation of the head of family, education of the head of family and total monthly income of the family were noted for each patient and on summation of all score, class of particular patient was obtained. ${ }^{10}$ Drugs prescribed by brand names and generic names were obtained from the 2017 edition of the WHO Model List of Essential Medicine. ${ }^{11}$

\section{Statistical analysis}

Data was analyzed using SPSS Version 16 software and results were expressed using descriptive statistics. According to modified Kuppuswamy scale 2018 scoring was given and corresponding socioeconomic Class I to V decided for victims.

\section{RESULTS}

In the present study, out of 64 cases, 37 (57.81\%) were men while $27(42.18 \%)$ were women (Figure 1). Maximum number of patients $24(37.50 \%)$ were from age group 2130 years followed by 16 patients $(25 \%)$ from $31-40$ years while 10 cases $(15.62 \%)$ were under 20 years age group. However, there were only $3(4.68 \%)$ patients who belonged to older age (61-70 years) and the mean age was $33.87 \pm 3.5$ years (SD) with an age range of $18-70$ years (Table 1 ).

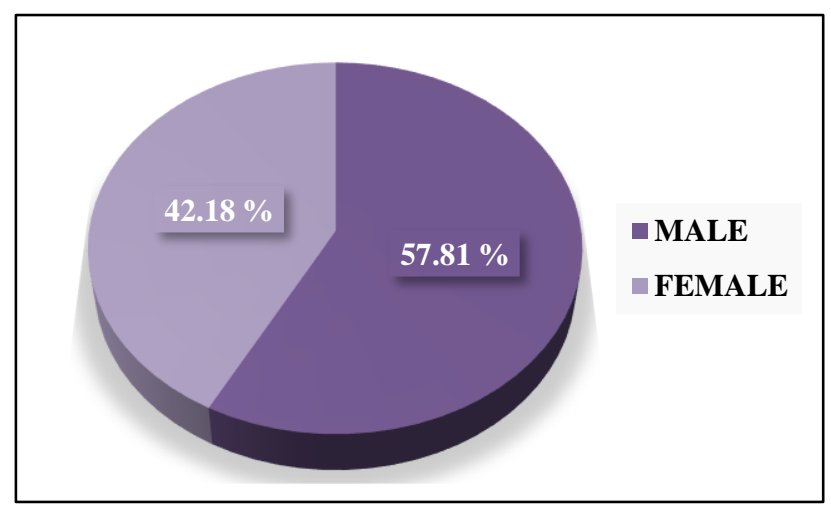

Figure 1: Gender distribution of cases.

Table 1: Age wise distribution of cases.

\begin{tabular}{|lll|}
\hline Age group (in years) & No. of cases & Percentage \\
\hline$<20$ & 10 & $15.62 \%$ \\
\hline $21-30$ & 24 & $37.50 \%$ \\
\hline $31-40$ & 16 & $25.00 \%$ \\
\hline $41-50$ & 05 & $7.81 \%$ \\
\hline $51-60$ & 06 & $9.37 \%$ \\
\hline $61-70$ & 03 & $4.68 \%$ \\
\hline Total & 64 & $100 \%$ \\
\hline Mean \pm SD* & & $33.87 \pm 3.5$ \\
\hline
\end{tabular}

Note:* SD - Standard Deviation

Among the 64 victims, there were $49(76.56 \%)$ cases of Intentional (suicidal) poisoning followed by 15 (23.44\%) cases of accidental poisoning (Figure 2). 
Maximum number of cases were under the socioeconomic upper lower class IV 48 (75\%) followed by lower middle class III $10(15.62 \%)$ and lower class V 6 (9.38\%). However not a single case was reported from upper I and upper middle class II (Table 2).

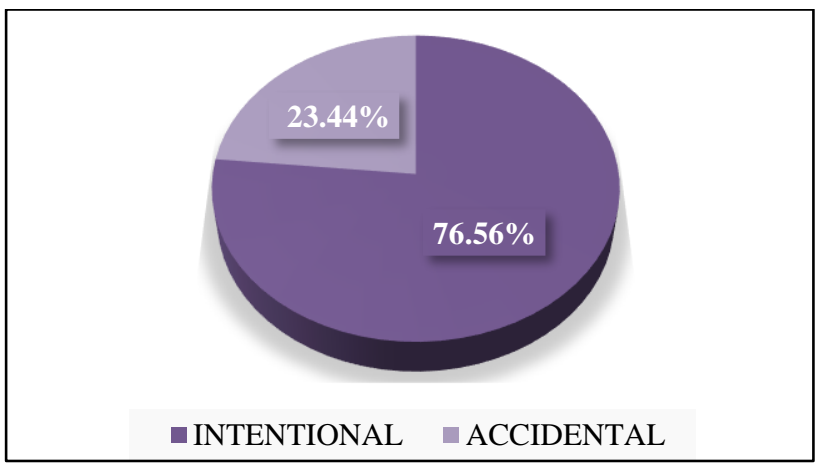

Figure 2: Mode of exposure in OP poisoning.

Table 2: Distribution of socioeconomic class*.

\begin{tabular}{|lll|}
\hline Kuppuswamy class & No. of cases & Percentage \\
\hline I-Upper & 0 & $0 \%$ \\
\hline II-Upper middle & 0 & $0 \%$ \\
\hline III-Lower middle & 10 & $15.62 \%$ \\
\hline IV-Upper lower & 48 & $75 \%$ \\
\hline V-Lower & 6 & $9.38 \%$ \\
\hline Total & 64 & $100 \%$ \\
\hline
\end{tabular}

Note: * - Modified 2018 Kuppuswamy scale

Most of the cases of $\mathrm{O} P$ poisoning were from rural areas $53(82.82 \%)$ followed by $11(17.18 \%)$ from urban background (Table 3 ).

Table 3: Rural-urban distribution of O P poisoning cases.

\begin{tabular}{|lll|}
\hline Residence & No. of cases & Percentage (\%) \\
\hline Rural & 53 & 82.82 \\
\hline Urban & 11 & 17.18 \\
\hline Total & 64 & 100 \\
\hline
\end{tabular}

Table 4: Atropine and pralidoxime profile.

\begin{tabular}{|ll|}
\hline $\begin{array}{l}\text { Total dose required in (mgs / } \\
\text { gms) / day and duration }\end{array}$ & Mean \pm SD \\
\hline Atropine & $37.89 \pm 63.63$ \\
\hline Pralidoxime & $10.07 \pm 26.87$ \\
\hline Total duration (number of days) & Mean \pm SD \\
\hline Atropine & $3.42 \pm 3.5$ \\
\hline Pralidoxime & $2.79 \pm 4.24$ \\
\hline $\begin{array}{l}\text { Atropine required from } \\
\text { admission till recovery }(\mathrm{mg})\end{array}$ & Mean \pm SD \\
\hline $\begin{array}{l}\text { Atropine requirement in } 1^{\text {st }} 24 \\
\text { hours }\end{array}$ & $18.93 \pm 5.65$ \\
\hline $\begin{array}{l}\text { Atropine requirement from } 24 \\
\text { hours onwards till final outcome }\end{array}$ & $19.21 \pm 57.98$ \\
\hline
\end{tabular}

Total daily mean dose required for Atropine and Pralidoxime were $37.89 \pm 63.63 \mathrm{mg}$ and $10.07 \pm 26.87 \mathrm{gm}$ respectively. Mean duration of Atropine and Pralidoxime given to patients were $3.42 \pm 3.5$ and $2.79 \pm 4.24$ days respectively. Mean atropine requirement in 1st 24 hours in (mg) was $18.93 \pm 5.65$ and from 24 hours onwards till recovery of patient in $(\mathrm{mg})$ was $19.21 \pm 57.98$ (Table 4).

Table 5: Core prescribing indicators.

\begin{tabular}{|lll|}
\hline Prescribing indicators & $\begin{array}{l}\text { Average/ } \\
\text { percentage }\end{array}$ & $\begin{array}{l}\text { WHO } \\
\text { reference } \\
\text { values }\end{array}$ \\
\hline $\begin{array}{l}\text { Average number of drug } \\
\text { per encounter }\end{array}$ & 4.4 & $(1.6-1.8)$ \\
\hline $\begin{array}{l}\text { Percentage of encounter } \\
\text { with antibiotics }\end{array}$ & $100 \%$ & $\begin{array}{l}20.0 \%- \\
26.8 \%\end{array}$ \\
\hline $\begin{array}{l}\text { Percentage of encounter } \\
\text { with injection }\end{array}$ & $100 \%$ & $\begin{array}{l}13.4 \%- \\
24.1 \%\end{array}$ \\
\hline $\begin{array}{l}\text { Percentage of drug } \\
\text { prescribed by generic }\end{array}$ & $46.31 \%$ & $100 \%$ \\
\hline $\begin{array}{l}\text { Percentage of drug from } \\
\text { essential drug list (WHO) }\end{array}$ & $70 \%$ & $100 \%$ \\
\hline
\end{tabular}

In this study, the average number of drugs per prescription which is an important index of the standard of prescribing, was 4.4; the percentage of encounter with antibiotics and injections was $100 \%$; the percentage of drugs prescribed by generic name was $46.31 \%$. Whereas percentage of drugs from essential drug list was found to be $70 \%$ (Table 5).

Table 6: Distribution of drugs prescribed.

\begin{tabular}{|lll|}
\hline Name of DRUGS & $\begin{array}{l}\text { Total no. of } \\
\text { drug }\end{array}$ & $\begin{array}{l}\text { Percentage } \\
\text { prescribe }\end{array}$ \\
\hline Inj Atropine & 61 & 23.10 \\
\hline Inj Pralidoxime & 61 & 23.10 \\
\hline Inj Cefotaxime & 59 & 22.35 \\
\hline Inj Ranitidine & 59 & 22.35 \\
\hline Inj Paracetamol & 01 & 0.38 \\
\hline Inj Ondensetaron & 01 & 0.38 \\
\hline Inj Mucomix & 03 & 1.14 \\
\hline Inj Haloperidol & 01 & 0.38 \\
\hline Inj Calcium gluconate & 02 & 0.75 \\
\hline Inj Hydrocortisone & 01 & 0.38 \\
\hline Inj Lasix & 01 & 0.38 \\
\hline Inj Vitamin K & 01 & 0.38 \\
\hline Inj Thiamine & 02 & 0.75 \\
\hline Inj Optineuron & 06 & 2.28 \\
\hline Inj Magnesium sulphate & 01 & 0.38 \\
\hline Tab Nephrozone & 01 & 0.38 \\
\hline Tab Sodamint & 01 & 0.38 \\
\hline Tab Udiliv & 01 & 0.38 \\
\hline Syp Kesol 200 ml & 01 & 0.38 \\
\hline Total & 264 & 100 \\
\hline
\end{tabular}

In total 64 patients, 264 drugs were prescribed, among them most frequently prescribed drug were Inj atropine and 
Inj pralidoxime $61(23.10 \%)$ each; followed by Inj Cefotaxime and Inj ranitidine $59(22.35 \%)$ each; whereas 11 drugs were prescribed only $1(0.38 \%)$ time for the treatment of the Organophosphate poisoning (Table 6).

Maximum percentage of cases were mild $41(64.06 \%)$ followed by moderate $18(28.13 \%)$ and severe $05(7.81 \%)$ (Figure 3).

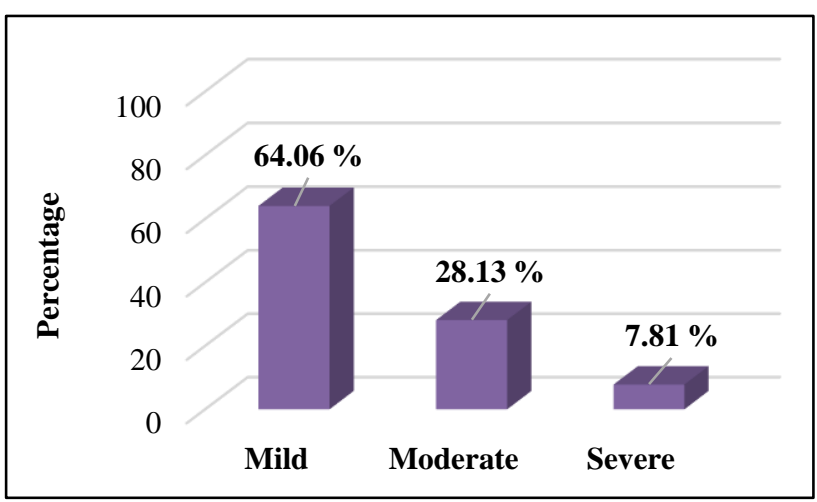

Figure 3: Severity of cases in $\mathrm{O} P$ poisoning.

Maximum number of cases $26(40.63 \%)$ were seen in month of July followed by June and August, while minimum number of cases were seen in month of May (Figure 4).

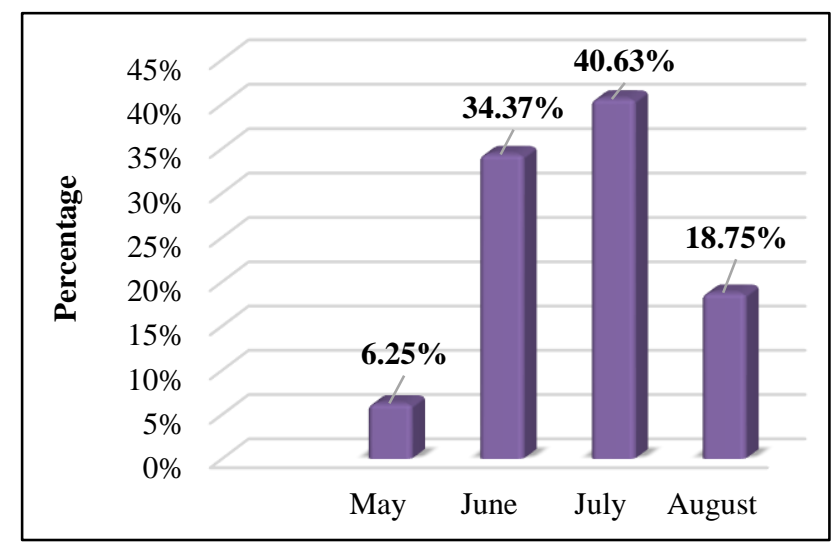

Figure 4: Months wise distribution of cases.

\section{DISCUSSION}

The occurrence of 64 cases of OPP in this tertiary care hospital over a period of four months highlights the seriousness of problem. In the present study, O P poisoning was more common in males $37(57.81 \%)$ than females 27 (42.18\%); the observation was similar with Revankar SP et al, and Prasad DR et al, study; however, Liu H X et al, Sidhart. T et al, found more number of female cases. ${ }^{4,12-14}$ Other investigator also shown comparable finding in Nepalese population. ${ }^{15,16}$ These observations may be attributed to the fact that pesticides are equally accessible to male and female farmworkers. In our study, the main age group involved (37.50\%) ranged between 21-30 years which is comparable with Revankar SP et al, Srivastava et al, Vaidya and Hulke et al, and Biswas $S$ et al, the younger age group vulnerability may be due to poverty, lack of education, unemployment and stressful life..,17-19 Among the 64 cases of poisoning, $49(75.56 \%)$ were Intentional (Suicidal) poisoning while $15(23.44 \%)$ Accidental poisoning and the finding comparable with Revankar S P. ${ }^{4}$ This high incidence of suicidal poisoning was probably because it is cheap, easily available and used as pesticide in agricultural farming throughout India. Authors have observed maximum cases 48 (75\%) from upper lower (IV) socio economic class followed by lower middle class (III) (Modified Kuppuswamy 2018 classification) the data comparable with Sidhart T, Rajesh. KS, Suvarna.M.Kstudy. ${ }^{14}$ Most of the cases in our study were from rural areas $(82.82 \%)$; The finding were comparable with Amarnath $\mathrm{M}$ et al, study while Sidhart T et al, reported more cases in urban area (61.53\%). ${ }^{14,20}$ The average number of drugs per prescription is 1.6-1.8 according to WHO which is an important index of the standard of prescribing, In our study it was 4.4 while it was 2.6 in Demeke B et al, study. ${ }^{21}$ Percentage of encounter with antibiotics in this study was $100 \%$ while $32 \%$ in Demeke $\mathrm{B}$ et al, study which is higher than the WHO reference value of $20.0-26.8 \% .^{21}$ The available literature on use of antibiotic prophylaxis in $\mathrm{O} P$ poisoning suggest that they did not offer any advantage over nonuse, on the contrary they carries the risk of development of super infection by more resistant organism. ${ }^{22,23}$ However use of prophylactic antibiotics in ventilator induced pneumonia in $\mathrm{O} P$ poisoning is beneficial. ${ }^{24}$ Prescribing by generic name is known to reduce the cost of drug treatment. It was $46.31 \%$ in present study, while Asari PDet al, study had similar observation. $^{25}$ Generic prescribing should be further encouraged as it is the best way to ensure accessibility of drugs to the patients especially in developing countries. ${ }^{26}$ Overuse of injections lead to increased cost and health hazards as non-sterile injections contribute to the transmission of hepatitis, HIV / AIDS and other blood borne diseases. In this study the percentage of encounters with injection was very high $(100 \%)$ than recommended WHO range $(13.4 \%-24.1 \%)$ while it is $(98.5 \%)$ in Asari PD et al, study. ${ }^{25}$ The percentage of drugs from essential drug list was found to be $70 \%$ which is less than the WHO standard value of $100 \%$ while it is $(66 \%)$ in Asari PD et al, study. ${ }^{25}$ The average daily requirement of Atropine per patient in present study was $37.89 \pm 63.63 \mathrm{mg}$. while Vijaykumar HN et al, study reported $74.82 \pm 22.39 \mathrm{mg}$ in randomized controlled trial. ${ }^{27}$ In the same study the investigator found less mean daily atropine requirement $(53.11 \mathrm{mg})$ in a group where Magnesium sulphate was given. ${ }^{27}$ Most of the victims in present study were mild $(64.06 \%)$ to moderate $(28.13 \%)$ in severity which justifies less average daily requirement of atropine. One patient received Inj. Magnesium sulphate parenterally in present study. Intravenous magnesium sulphate given on the 1 st day of admission in $\mathrm{O} \mathrm{P}$ poisoning cases have shown to decrease hospitalization period and improve outcome. ${ }^{28,29}$ Maximum number of patients $61(23.10 \%)$ received Inj atropine and inj. pralidoxime followed by inj. cefotaxime 
and Inj. ranitidine 59 (22.35\%). In Dixon EW et al, study benzodiazepines were widely used in $\mathrm{O} \mathrm{P}$ poisoning but in this study, they were not prescribed. ${ }^{30}$ However, their efficacy as primary treatment is not established. Highest number of O P poisoning cases $26(40.63 \%)$ were seen in month of July followed by June and August in rainy season in present study, Sidhart $\mathrm{T}$ et al, study had similar findings. ${ }^{14}$ However, Maharani $\mathrm{B}$ et al, reported more poisoning cases during summer. ${ }^{31}$ The regulatory authority should consider for banning the sale of very toxic type of organophosphates compounds used commonly as pesticides in farming.

The limitations of the study were: due to medico legal concern patients below 18 years of age and seriously ill patients were excluded. This was short duration, small sample size and single center study with regional focus.

\section{CONCLUSION}

In present study, the younger age males with lower socioeconomic class with rural background were more vulnerable for organophosphate poisoning. The high incidence of intentional (suicidal) poisoning in young adult farmworkers can be reduced by psychological counselling and rural employment generation. Regular training of resident doctors in good clinical practice is need of hour so that WHO core prescribing indicators are followed. All clinicians to strictly follow the antibiotic policy of the institute and avoid prophylactic use of antibiotics in $\mathrm{O} P$ Poisoning. Further research is needed in this region of central India with longer duration and larger sample size to comment on seasonal variation of victims and to establish the guidelines for treatment of organophosphate poisoning.

\section{ACKNOWLEDGEMENTS}

Authors are sincerely grateful to the Honorable Dean, Government Medical College Akola and Professor and HOD of Medicine Department for permitting authors in carrying out present research project at the tertiary care hospital.

\section{Funding: No funding sources}

Conflict of interest: None declared

Ethical approval: The study was approved by the Institutional Ethics Committee (Letter. No/GMCA/EC/Patho/451A/2018)

\section{REFERENCES}

1. World Health Organization. The impact of pesticides on health. Available at: http://www.who.int/mental_health/preventin/suicide/ en/pesticidesHealth2.pdf.

2. National Crime Record Bureau. Accidental deaths and suicides in India. Ministry of home affairs, New Delhi, government of India. Available at: http://ncrb.nic.in/adsi2008/suicides-08.pdf.
3. Aaron R, Joseph A, Abraham S, Muliyil J, George K, Prasad $\mathrm{J}$ et al. Suicides in young people in rural southern India. Lancet. 2004;363:1117-8.

4. Revankar SP, Vedavathi H. Study on organophosphate poisoning analysis and pharmacotherapeutic outcome in tertiary care hospital. Int J Basic Clin Pharmacol. 2016 23;4(5):936-40.

5. Namba T, Nolte C T, Jackrel J, Grob D. Poisoning due to organophosphate insecticides, acute and chronic manifestation. Am J Med. 1971;50:475-92.

6. Eddleston M. Patterns and problems of deliberate selfpoisoning in the developing world. QJM. 2000;93(11):715-31.

7. Kalantri SP, Jajoo SU. Protocol for management of pesticide poisoning. J Occup Environ Med. 2012;16:93-8.

8. Udaykumar P. Medical Pharmacology. 3rd ed. New Delhi: CBS Publishers. 2006:468-74.

9. Tripathi KD. Essentials of Medical Pharmacology. 6th ed. New Delhi. Jaypee Publications; 2013:98.

10. Saleem SM. Modified kuppuswamy scale updated for year 2018. PARIPEX Indian J Res. 2018;7(3):217-8.

11. WHO. Model list of essential medicine March 2017(Amended 2017). 20th list.1-62. Available at: Available https://www who.int/medicines/publications/essential medicines/en/.

12. Prasad DR, Jirli PS, Mahesh M, Mamatha S. Relevance of plasma cholinesterase to clinical findings in acute organophosphorous poisoning. Asia Pacific J Med Toxicol. 2013;2(1):23-7.

13. Liu HX, Liu CF, Yang WH. Clinical study of continuous micropump infusion of atropine and pralidoxime chloride for treatment of severe acute organophosphorus insecticide poisoning. J Chinese Med Assoc. 2015;78(12):709-13.

14. Timsinha S, Shah RK, Kar SM. Sociodemographic characteristics and assessment of severity in organophosphorus poisoning in a tertiary care hospital. Int J Res Med Sci. 2017;5(9):3786-93.

15. Bhattarai N, Rauniyar A, Chaudhary D, Jaiswal S, Banthia P, Rana BB. Patterns of organophosphorous poisoning attending a teaching hospital. J Nepal Med Assoc. 2006;45(162):228-32.

16. Laudari S, Patowary BS. Analysis of Organophosphorus compound poisoning patients attending CMS-TH, Bharatpur, Nepal. J Coll Med Sci Nepal. 2011;7(4):9-19.

17. Srivastava A, Peshin SS, Kaleekal T, Gupta SK. An epidemiological study of poisoning cases reported to the national poisons information centre, All India Institute of Medical Sciences, New Delhi. Human Experiment Toxicol. 2005 Jun;24(6):279-85.

18. Vaidya YP, Hulke SM. Study of trends of poisoning in the cases reported to government hospital, Yavatmal. Chron Young Scientists. 2012 Jan 1;3(1):63.

19. Biswas S, Haldar M, Mondal KK, Dalai C, Bhattacharyya S, Chatterjee S, Das AK. Rationally used antidotes in organophosphorus poisoning 
prevents suicidal death. J Indian Acad Forensic Med. 2013;35(1):51-4.

20. Mishra A, Shukla SK, Yadav MK, Gupta AK. Epidemiological study of medicolegal organophosphorus poisoning in central region of Nepal. J Forensic Res. 2012;3(9):1000167.

21. Demeke B, Molla F, Assen A, Melkam W, Abrha S, Masresha B. Evaluation of drugs utilization pattern using WHO prescribing indicators in Ayder referral hospital, Northern Ethiopia. IJPSR. 2015;6(2):343-7.

22. Banerjee I, Tripathi SK, Roy AS. Clinicoepidemiological characteristics of patients presenting with organophosphorus poisoning. North Am J Med Sci. 2012;4(3):147.

23. Schultz L, Lowe TJ, Srinivasan A, Neilson D, Pugliese G. Economic impact of redundant antimicrobial therapy in US hospitals. Infect Control Hospital Epidemiol. 2014;35(10):1229-35.

24. Raphael M, Karimzad SH, Agarwal J, Bhandakar AA, Thunga G, Shreedhar N, et al. Prevalence of ventilator acquired pneumonia in organophosphorus poisoning patients in tertiary care hospital. Int J Drug Develop Res. 2015;7(4):005-8.

25. Asari PD, shah SM, Amin AJ, Patel ND. Drug utilization study on acute poisoning cases treated at a tertiary care hospital in western part of India. Asia Pacific J Med Toxicol. 2016;5(1):20-4.

26. Teshale C, Hussein J, Mussa S. Assessment of the quality of pharmaceutical service in Jimma zone, Oromia Regional State, South west Ethiopia. Int J Pharma Teaching Pract. 2014;5(2):960-6.
27. Vijayakumar HN, Sudheesh Kannan CT, Duggappa DR, Gowda KV, Nethra SS. Study of effect of magnesium sulphate in management of acute organophosphorous pesticide poisoning. Anesthesia Essays Res. 2017 Jan;11(1):192.

28. Blain PG. Organophosphorus poisoning (acute). BMJ Clin Evidence. 2011;2011.

29. Pajoumand A, Shadnia S, Rezaie A, Abdi M, Abdollahi M. Benefits of magnesium sulfate in the management of acute human poisoning by organophosphorus insecticides. Human Experiment Toxicol. 2004;23(12):565-9.

30. Dickson EW, Bird SB, Gaspari RJ, Boyer EW, Ferris CF. Diazepam inhibits organophosphate-induced central respiratory depression. Acad Emergency Med. 2003;10(12):1303-6.

31. Maharani B, Vijayakumaris N. Profile of poisoning cases in a Tertiary care Hospital, Tamil Nadu, India. J App Pharmaceut Sci. 2013;3(1):91.

Cite this article as: Bhagwate ST, Warbhe RA, Chavhan GK, Yuwnate AH, Wankhade AD. Sociodemographic profile of patients and prescribing trend of drugs in organophosphate poisoning at tertiary care teaching hospital in Central India: a descriptive study. Int J Basic Clin Pharmacol 2019;8:897-902. 